\title{
Hvem er ærens konge, der?
}

\author{
Mowinckel og Händel - to receptionshistoriske læsninger \\ af Sl 24 \\ Cand.theol. \\ Andreas Riis Damgaard
}

\begin{abstract}
Sigmund Mowinckel created a highly influential interpretation of the Psalter. In this interpretation, Ps 24 played a particularly important role due to its antiphonic style. The antiphonic style of the psalm is widely represented in the reception history of the psalm - especially in classical music. For example, Handel's chorus piece Lift up ye Heads in his oratorio Messiah is structured in an antiphonic manner. Mowinckel's exegesis and the music composed by Handel have similar structures in their representations of Ps 24 - in spite of the different aims of their interpretations. However, both interpretations are concerned with God's victory over death. It is fruitful to note the similarities of the two interpretations, because they suggest either a Christian hermeneutical background to Mowinckel's enthronement festival or an antiphonic style in the text itself.
\end{abstract}

Keywords: Mowinckel - Psalm 24 - Sitz-im-Kultus - Psalm reception Gunkel - Händel - Messiah - Oratorium - Baroque - Old Testament Psalms - Form Critical School - History of Reception - liturgy - creatio continua - Cult - Typology

\section{I: Indledning, fremgangsmåde og tekstanalyse}

Sl 24 er en af de gammeltestamentlige salmer, som har været udsat for alle tænkelige forskningshistoriske paradigmer, og som i tidernes løb er blevet dateret til både før, under og efter eksilet. Salmen har været særlig central i kirkemusikken, hvor den er blevet brugt som en liturgi, typisk en vekselsang, men også i den klassiske musik. Den hyppigste fortolkning af salmen har været messiansk, ikke mindst i den katolske kirkes liturgi, hvor den benyttes til et ritual i gudstjenesten påskemorgen - Kristus identificeres her med salmens allusion til “Ærens konge”, som inddrager. ${ }^{1}$ I Folkekirken benyttes

1. Sl 24,7-10 kendes også fra J. P. E. Hartmanns Collect til Julefest. Hartmann benytter også her en vekselsangstruktur, hvor mandsstemmerne synger om at: "Ærens Konge må inddrage”. Således benyttes SI 24,7-10 i denne sammenhæng til at forklare Jesu fødsel. 
salmen som læsning til 1. søndag i advent og synges ofte i gendigtet form i adventssalmen af N.J. Holm Gør døren høj, gør porten vid. Den centrale norske, gammeltestamentlige ekseget Sigmund Mowinckel mente også, at Sl 24 var skrevet som et led i et kultisk ritual, der blev benyttet til en israelitisk høst- og nytårsfest ${ }^{2}$. Tankerne om den såkaldte tronbestigelsesfest blev i særlig grad udviklet i Mowinckels mest centrale og måske mest omstridte værk Psalmenstudien II fra 1922. ${ }^{3}$ Den såkaldte kultiske læsning af størstedelen af Salmernes Bog havde en enorm gennemslagskraft for Mowinckels tid for ikke at nævne kommende generationer af gammeltestamentlige eksegeter. I dag forkaster langt de fleste eksegeter Mowinckels kultiske læsning, men der findes stadigvæk få, som plæderer for tolkningssystemet.

Der lader til at være fællestræk mellem Mowinckels læsning og den hyppige musikalske fortolkning af Sl 24 i den klassiske musik. Et godt eksempel på sådan en musikalsk fortolkning af salmen finder man i G.F. Händels Messias (HWV 56) i kor 30 Lift up ye Heads. Begge udlægninger af Sl 24 - Mowinckels eksegese og Händels musikalske fortolkning - understreger de samme motiver og hovedtræk og repræsenterer begge nedslag i salmens receptionsog fortolkningshistorie. De fællestræk, som kan påpeges mellem de to læsninger, er interessante, fordi de giver anledning til at overveje, om Sl $24 \mathrm{~s}$ tekst indbyder til én særlig fortolkning, eller om Mowinckels eksegese var præget af hans kirkelige og kulturelle baggrund. Mowinckels læsning var uomtvisteligt for "kreativ". Dog er han nyttig i denne artikels øjemed, da han forsøger at rekonstruere kultiske riter ud fra de gammeltestamentlige salmer, og derved gør han Salmernes Bog til en form for "libretto" til kulten. I Psalmenstudien II er der derfor konkrete beskrivelser af det kultiske drama, som Mowinckel mener, at han kan finde i salmerne. Ud fra den betragtning står Händels kunstneriske fortolkning af Sl 24 ikke så langt fra Mowinckels eksegetiske projekt. Det er muligvis derfor, at læsningerne deler så mange fælles strukturer - på trods af at de to læsninger sigter på to meget forskellige fortolkninger af salmen.

I det følgende vil jeg indledningsvis gennemgå Sl 24s tekst (I), som naturligt falder $i$ tre overordnede dele: a) v1-2 b) v3-6 c) v710. Derefter vil jeg redegøre for Mowinckels læsning af psalteret og sætte Sl 24 i forbindelse med tronbestigelsesfesten (II). Herefter præsenterer jeg Händels historiske kontekst i forbindelse med Messiah a Sacred Oratorium (1741) og gennemgår Händel og Jennens

2. Mowinckel foretrækker egentlig ordet Nytårsfestival, da det netop betoner den årlige, tilbagevendende karakter, som han hævdede, at nytårsfesten havde.

3. Sigmund Mowinckel, Psalmenstudien II: Das Thronbesteigungsfest Jahwäs und der Ursprung der Eschatologie, (Amsterdam: Paul Schippers 1961 (1921)) 
fortolkningsstrategier i værket (III). Derefter gennemgår jeg Händels musikalske fortolkning af Sl 24,7-10 i Messias (IV), og slutteligt diskuterer jeg de tematiske og strukturelle sammenhænge i de to receptionshistoriske fortolkninger af Sl 24 s tekst (V).

\section{Gennemgang af teksten i Sl 24}

\section{Sl 24,1-2: Derfor er Jahve kongen - skabelseshymnisk lovprisning}

De to overordnede tematikker i den indledende hymne, $a$, er, at Jahve er verdens hersker og ejer (v1) og Jahve som verdens skaber og opretholder (v2). Han ejer hele jordens fylde (מלואה) og alt, hvad der bor/ hviler (ישב) der. Præpositionssyntagmet i begyndelsen af anden linje, ליהוה, understreger Jahves verdensherredømme og almagt. Endvidere understreges denne tematik igen i glossen מלואה, som bør oversættes med fylde eller helhed; Kraus beskriver det således: "Gemeint ist der gesamte Inhalt der geschaffenen Welt". ${ }^{4}$ Det er også værd at notere, at Salmisten benytter to gloser, som grundlæggende betegner verden, תenviser til selve jorden, hvorimod תבל .תבל og ארץ den beboede jord. Jahve har altså skabt jorden (creatio prima) og beskytter den fra kaosmagterne (creatio continua).

Brugen af pronominer er et centralt træk i Sl 24. I Sl 24,2 optræder salmens første demonstrative pronomen, הוא. Tætheden af pronominer stiger gradvist fra slutningen af midterdelen (Sl 24,3-6) og yderligere ind i den afsluttende del (Sl 24,7-10). De demonstrative pronominer binder derfor bue mellem han som ejer, skaber og opretholder, og han som er herligheds konge og hærskarernes Herre, som det beskrives i Sl 24,7-10.

\section{Sl 24,3-6: Indgangstora: moralkatekismus og dydskatalog}

S1 24s anden del, $b$, består primært af et dobbeltspørgsmål om, hvem der kan stige op på Jahves bjerg (הר) og om hvem, der kan stå på hans hellige sted (מקום). Dette besvares i v4-5 med i alt fire svar, som forekommer i par af to. ${ }^{5}$ Den udbredte holdning i forskningen er, at disse to substantiver refererer til tempelbjerget i Jerusalem. Mowinckel

4. Hans-Joachim Kraus, Psalmen, BKAT XV (Neukirchen-Vluyn: Neukirchener Verlag 1961), 93-94.

5. Phil J. Botha: "Answers Disguised as Questions: Rhetoric and Reasoning in Psalm 24", OTE 22 (2009), 535-553. 
beskriver således verballeddet עלה i S1 24,3 ift. bjerget ${ }^{6}$ : "Fast uttrykk for den kultiske prosesjon op til templet" (Mowinckel 1955, 67). Der oplistes fire betingelser i to par. Begge par betegner henholdsvis den ydre og den indre gerning. I det første par påkræves det, at man skal have rene hænder (כפים נקי) og et purt hjerte (לבב בר). Hænderne betegner altså her handling/gerning, mens hjertet betegner tanken. Det andet par er ikke at fare med løgn og ikke at sværge falsk. Dette par er ikke lige så åbenlyst repræsentativt for de to sider af mennesket, men som Botha overbevisende skriver:

The two parallel pairs complement each other since the second pair can also be viewed as relating respectively to thought processes ('does not lift up his soul to deception/idols') and action ('does not swear to deception/idols') (Botha 2009, 541).

Botha fortolker altså menedshandlingen som afgudsdyrkeri, en læsning som desuden støttes af Hossfeld og Zenger. ${ }^{7}$ Dernæst beskrives handling og tanke igen, men i en negativ forstand - her tales altså om dem, som skal nægtes adgang til Jahves bjerg. Den samme tankegang går igen i Sl 15,2. Sl 15 og 24,3-6 beskriver begge såkaldte leges sacrae. Ligesom i S1 15 og 24,3-6 besvares spørgsmålet med et slags dydskatalog, hvor der fokuseres på renhed. Mowinckel mener, at Sl 15 og 24,3-6 tilsammen fungerer som: "moralkatekismus om hvordan den mann skal være som vil være 'Jahves gjest' og 'velsignet i evighed"” (Mowinckel 1955, 66).

\section{Sl 24,7-10: At arens konge må drage ind - antifonal vekselsang}

Sl 24,7-10 er i Mowinckels læsning åbningen ind til et nyt liturgisk afsnit, en portliturgi. Betragtningen baseres på passagens antifonale ordlyd og det talende subjekts befaling om at portene, שערים, og de ældgamle døre, פתחי עולם, skal slås op for Jahve. Det er interessant, at portene i tekststykket er personificeret. Mowinckel påpeger, at dette tjener et digterisk og mytisk formål (Mowinckel 1955, 66). Mowinckel hævder, at salmen er den tekst, som lå til grund for et ritual, hvor Israels folk stod foran templet for at "drage ind" i det med ærens konge tronende over/i arken. Tempeltoraen i v3-6 er derved en

6. Mowinckel oversætter tekststykket med: "Hvem får gå op til Herrens Fjell, og hvem får dvele på hans helgsted?” i Sigmund Mowinckel: Det Gamle Testamente Skrifterne 1. Del, oversat av Sigmund Mowinckel, (Oslo: Forlagt av H. Aschehoug \& Co. 1955), 66.

7. Frank Lothar Hossfeld \& Erich Zenger, Die Neue Echter Bibel, kommentar zum Alten Testament mit der Einheitsübersetzung (Würzburg: Echter Verlag 1993), 160. 
gennemgang af de renhedsregler, som skal overholdes af folkeskaren, hvis portvagterne skal kunne slå templets porte op, så den kultiske procession kan fortsætte yderligere ind i templet.

Jahvetitlen מלך הכבוד forekommer for første gang i v7. Den benyttes כבוד עderligere tre gange i v8; 9; 10. I 1992-oversættelsen oversættes med are, således at konstruktformen samlet oversættes med arens konge. I Pentateuken oversættes כבוד dog oftere med herlighed end are, som fx i Ex 24,15-18. Glosen er kompleks, da den ligeledes indeholder forestillinger om flammende ild, skyer og andre naturfænomener. כבוד er et dækkende udtryk for den gammeltestamentlige opfattelse af Jahve, da han er virkelig, men samtidig uhåndgribelig, som ild i en sky. ${ }^{8}$ I SI 24 uddyber כבוד-prædikatet salmens kongemetaforik på den måde, at udtrykket fortæller noget om Jahves måde at være konge på. Den sidste del af salmen, $c$, anslår således et centralt tema: Jahve som den guddommelige kriger, hærskarernes Herre.

Brugen af pronominer i Sl 24 er interessant, og de kan opfattes som indikatorer på en kultisk brug af salmen. I del $a$ og $b$ af Sl 24 benyttes der kun to pronominer. I vers 2 benyttes הוא til at beskrive "Han", som har grundlagt verden, "Han", som holder den oven vande. I vers 6 benyttes it til at beskrive "den" generation, som søger Jahve. Men brugen af demonstrative pronominer intensiveres i del $c$. I vers 8 a benyttes זה i spørgsmålet om, hvem herlighedens konge er. I Sl 24,10 optræder der tre demonstrative pronominer. זוא optræder to gange og זה זה זה oversættes det ikke i 1992-oversættelsen, men הוא (han) oversættes. Med denne korte analyse af pronominernes placering kan man uddrage, at der optræder flest demonstrative pronominer i den sidste del af salmen (7-10), specielt i v10. Intensiveringen er relevant i forbindelse med Mowinckels kultiske læsning af salmen. Mowinckel forestiller sig, at processionen er nået til templet og befaler portvagterne at slå portene op for herlighedens konge. Tempelvagterne spørger Israels folk om, hvem herlighedens konge der er. Portvagterne spørger altså her til Jahve, der troner usynligt på/i arken. Folkeskaren bekender dernæst, at det er Jahve mægtig i krig og strid. Det demonstrative pronomen bruges her som et slags sakramentalt udtryk, som slutter fra myte og metafysik til rite og virkelighed.

8. Hans J. Lundager Jensen, Gammeltestamentlig Religion - en indforing (København: Anis 2010 (1998)), 100. 


\section{II: Psalteret som kultens arkimediske punkt - Mowinckels positionering og læsning}

Mowinckel var i høj grad påvirket af sin underviser, formkritikkens fader, Hermann Gunkel. ${ }^{9}$ Mowinckel videreudviklede Gunkels formkritiske principper, idet han forsøgte at læse salmerne ud fra deres kultiske brug frem for at forsøge at finde frem til en oprindelig "ur-form" i teksterne selv. Dette gjorde Mowinckel ved at forsøge at rekonstruere kultens ritualer som en slags libretto og ritualbog til kulten og ved samtidigt at fokusere på andre kultiske religioner i den gammeltestamentlige omverden.

Allerede tidligt i Psalmenstudien II gør han op med de to mest dominerende læsninger af tronbestigelsessalmerne i hans samtid. Det er henholdsvis den samtidshistoriske læsning og den eskatologiske læsning. Igennem dette opgør tager Mowinckel de første skridt udi sin kultiske fortolkning af psalterets tekster.

\section{Opgør med den samtidshistoriske lasning og den eskatologiske lasning}

Hvad angår die zeitgeschichtliche Deutung, så påpeger Mowinckel først og fremmest, at dette er en problematisk læsning, da der mangler historiske referencer, arkæologiske fund og andre former for hjemmel, hvis man skal kunne godtage læsningen (Mowinckel 1961 (1921), 10). Dernæst understreger Mowinckel, at salmerne til Jahves tronbestigelsesfest er så hyperbolske, at man umuligt kan læse dem ind i en bestemt samtidshistorisk kontekst (Mowinckel, 1961 (1921), 12). Dette har ifølge Mowinckel resulteret i en overflod af fejllæsninger af psalteret. Navnlig har læsningen henledt forskere til at læse tronbestigelsessalmerne eskatologisk. Det gælder eksempelvis læsningen af Sl 46,10: "Han gør en ende på krige, over hele jorden, han brækker buen og knækker spyddet, stridsvognene brænder han op" (DO 1992), som en eskatologisk fremtidsvision. Mowinckel påpeger i denne forbindelse ligesom Kittel og Gunkel, at det ikke er frugtbart at læse Sl 46 samtidshistorisk. Det begrundes primært med, at salmen beskriver Jerusalems vandløb (Sl 46,5). Eftersom der ikke er et vandløb i Jerusalem, må det forstås metaforisk. Gunkel fremsatte den påstand, at verset udelukkende kan læses sammen med $\mathrm{Ez}$ 47s beskrivelse af tempelkilden og den paradisiske flod fra Genesis. Ydermere hævder Mowinckel i Psalmenstudien II, at der ikke

$\overline{9 .}$ Det bør påpeges, at Gunkel aldrig anerkendte Mowinckels discipelskab, også selvom Mowinckel dedikerede Psalmenstudien II til Gunkel: "in Dankbarkeit". 
er ét eneste ord i selve psalteret, som beskriver en direkte eskatologisk vision.

Mowinckels anden primære anke imod den eskatologiske læsning er, at skribenterne, som skrev salmerne, taler ud fra noget allerede erfaret. Således tales der ikke om noget direkte futurisk, men om noget erfarings- og erindringsbaseret. Mowinckel hævder i den forbindelse, at psalterets skribenter rent faktisk har set Jahve stige op på tronen. De har erfaret, at han bor i Jerusalem (Sl 46,6), at hans "hellige skrin"10 befinder sig i Salem på Zion (Sl 76,3), og at han i procession er blevet båret til templet (Sl 132; 84; 24; 118). Det er grundlæggende denne rituelle samtidighed, som bliver det centrale punkt i Mowinckels kultiske læsning af psalteret. Det er i denne henseende, at man taler om, at Mowinckel nyfortolkede Gunkels litterære princip Sitz-im-Leben til det såkaldte Sitz-im-Kultus. Gunkel fulgte ikke eleven Mowinckels læsning, da han mente, at den var for fantasifuld.

\section{Grønbech og Gunkel - Den Nare Orient og Sitz-im-Kultus}

Mowinckel fremhæver i Psalmenstudien II, at det grundlæggende problem med salmeforskere og eksegeters hidtidige fortolkning af psalteret i det hele taget er, at de ikke forstår, hvad kult er. I den forbindelse fremhæver Mowinckel en længere række af kultiske religioner og disses forhold til det dramatisk-mytiske. Hermed ønsker han at understrege det universelle i det kultiske. Mowinckels opfattelse af det kultiske blev i høj grad baseret på en blanding af Vilhelm Grønbechs forståelse af primitiv religion og de formkritiske opdagelser, som Gunkel var stødt på i sit arbejde særligt med Genesis og Salmernes Bog. ${ }^{11}$ Grønbechs arbejde med at forstå naturmenneskets verdensopfattelse fik sit klareste udtryk i hans lille, klassiske afhandling Primitiv Religion fra 1915. Med "det primitive", som Grønbech ville beskrive i værket, mente han at:

10. Sådan oversætter Mowinckel selv ארון הברית.

11. Sådan som det blandt andet påpeges i Martin R. Hauges artikel "Sigmund Mowinckel and the Psalms - a query into his concern”, SJOT 2 (1988), 56-71. For en grundigere gennemgang af forholdet mellem den skandinaviske og tyske eksegese i første halvdel af det 20. årh., se Jesper Høgenhavens artikel "Fjenden fra Nord - Nedslag i den skandinaviske gammeltestamentlige forskning i første halvdel af 1900-tallet”, DTT 79 (2017), 261-277. Høgenhaven påpeger her blandt andet en sammenhæng i den skandinaviske eksegese efter Første Verdenskrig, hvor eksegeter som Johannes Pedersen og Mowinckel i nogen udstrækning gør op med den optimistiske tro på udvikling og fremskridt og satte den europæiske forskning op på en objektiv rangstige eller som endemålet i en kulturhistorisk evolution. 
... det betegner en kultur der har umiddelbar føling med naturomgivelserne, i modsætning til den civilisation der har sit centrum i byen og er udgået fra og bestemt af bymenneskers oplevelser. ${ }^{12}$

Grønbechs afhandling var ligeledes et forsvar mod evolutionisternes opfattelse af det "primitive". Den var således et modangreb på den opfattelse, at der går en linje fra magien til religionen og videre til videnskaben. I stedet accentuerede Grønbech, at man må forstå det kultiske og rituelle i dets forhold til opfattelsen af kosmos og kaos (Grønbech 1948, 38-48). Forsøget på at forstå fortidens kult og kultdeltagernes verdensanskuelse er begge centrale tematikker $\mathrm{i}$ Mowinckels forskning og hentede inspiration i Grønbechs forståelse af netop disse emner.

Den anden primære indflydelse kom fra Gunkels formkritiske forskning, som vandt stort indpas i kredsen omkring den Religionsgeschichtliche Schule. I Mowinckels fortolkning af psalteret fokuserede han i høj grad på den babylonsk-assyriske kults nytårsfest, hvor Marduk/Ashurs kamp imod et urmonster, et søuhyre kaldet Tiamat, blev ihukommet igennem symboler og pantomimespil. I denne fejring af en guddommelig kongeindsættelse i en anden kult mente Mowinckel at finde støtte til sin rekonstruktion af specifikke ritualer i den israelitisk-jødiske kult.

Den Nære Orients religioners tætte tilknytning til den israelitiskjødiske kult er ganske central i Mowinckels argumentation. I særdeleshed er, hvad Mowinckel kalder "kongemotivet", en af de vigtigste temaer, som både er fremtrædende i den babylonsk-assyriske religion og i den israelitisk-jødiske opfattelse af Jahve. Dette såkaldte kongemotiv sporer han i sin rekonstruktion af tronbestigelsesfesten i den israelitisk-jødiske religions kult. Kongemotivet var et udtryk for den opfattelse, at guden var kongen. I de gammeltestamentlige skrifter er det også et velkendt motiv. Fx i Esajas' bog hvor der er adskillige eksempler på det. Jahve omtales som Jakobs konge (Es 41,21) og ligeledes som Israels konge. Da Esajas kaldes til profet, udbryder han, at han har set kongen, hærskarernes Herre (Es 6,5). Mowinckels beskrivelse af tronbestigelsesfesten omkring Marduk i Psalmenstudien II er næsten analog med hans rekonstruktion af Jahves årlige tronbestigelsesfest. Navnlig tillægger han de "klassiske" tronbestigelsessalmers udråb יהוה מלך, Jahve er blevet konge, stor betydning. Yderligere opfatter han dem som identiske med lignende

12. Vilhelm Grønbech, Primitiv Religion, (København: Hans Reitzels forlag 1948), 10. 
kongeproklamationer i Marduks tronbestigelsesfest i den babylonske skabelsesmytologi i Enuma Elish-skrifterne.

Mowinckel forsøger at beskrive, hvorledes man skal opfatte kulten. I Mowinckels optik misforstår alt for mange nemlig, hvilket stof kulten er gjort af. Derfor beskriver han en lang række af forskellige kultsamfund, for at vise, hvad der menes med kult. Han begynder afsnittet Beispiele med Tierdramen der Australier, et emne der ligeledes interesserede Grønbech (Grønbech 1948, 12-14). Efter at have gennemgået nordgermanernes og mexicanernes kulter, hellenistisk mysteriekult og æegyptisk mytologi, når han til den kristne "kult". Her beskriver han blandt andet den romersk-katolske kirkes kultiske praksis og dens forhold til det kultisk-mytiske drama. Mowinckel fokuserer her på alterets sakramente og den bagvedliggende liturgi. Når man modtager nadveren, for at mindes Jesu lidelse og offeret på Golgata, deltager man i et kultisk-sakramentalt drama, hvor Jesu Kristi legeme og blod modtages. Transsubstantiationslæren demonstrerer derved den kultiske aktualisering af det mytologiske i Kristi sonoffer. Det er selve transsubstantiationen og konsekrationen af nadverelementerne, der er central i den katolske forståelse af sakramentet (Mowinckel 1961 (1921), 32-33).

Kulten er i Mowinckels optik en institution, hvor dramatik og ritus tjener til at erindre og genopleve religionens bagvedliggende mytologi. Udover misforståelsen af selve kulten, mener Mowinckel, at man for ensidigt har benyttet sig af P som kildemateriale til kultens riter. Mowinckel skriver: "Die zweite Hauptquelle unserer Kenntnis des Kultes, den Psalter, hat man bis jetzt nicht als solche würdigen wollen.” (S. Mowinckel 1961 (1921), 36). Det arkimediske punkt i Mowinckels forståelse af den israelitisk-jødiske kults dramatik og dens ihukommelse af mytologien er derfor psalteret, som han opfatter som kultens "libretto", dens ritualbog. Mowinckels kultisk-liturgiske læsning befinder sig herved i en konstant dobbeltbevægelse. Psalteret afspejler kultisk brug, men henter sideløbende sin betydning fra et ritual. Ifølge Mowinckel må kultens ritualer rekonstrueres ud fra salmerne, men samtidigt med blik for andre nærorientalske kulterer og deres rituelle praksis.

\section{III: Mowinckels tronbestigelsessalmer og en kultisk rekonstruktion af forløbet S1 132; 84; 24; 118}

Gunkel kategoriserede SI 47; 93; 96; 97; 99 som tronbestigelsessalmer. Mowinckels læsning inkluderer et større antal af salmer i denne 
kategori. ${ }^{13}$ Mowinckel læser dem som forskellige liturgiske og kultiske led i tronbestigelsesfesten. Derved definerer han ikke tronbestigelsessalmerne ud fra forestillingen om Jahve som konge, men ved vidnesbyrd om kultens aktualisering af tronbestigelsen. I Mowinckels forsøg på at rekonstruere processionen til templet benyttes fire salmer, for at klarlægge ruten til templet under tronbestigelsesfesten.

Mowinckel læser Sl 24 som et led i en kultisk festprocession. På baggrund af forløbet igennem Sl 132; 84; 24; 118 forsøger han at rekonstruere et fest- og kongeoptog som et kultisk-mytisk skuespil. Optogets formål var at ihukomme arkens første indtog i Jerusalem (2 Sam 6,12) (Mowinckel 1951, 172). Kongeindtogets opbygning er parallelt med det forløb, som David er igennem, når han fører arken ind i Davidsbyen (עיר דוד). Derfor begynder Jahves kongeindtog uden for tempelborgen, da man mindes de tre måneder, hvor arken stod i Obed-Edoms hus. Dette er Sl 132s kontekst i Mowinckels læsning: Folkemasserne valfartede ind igennem Jerusalems porte, imens de sang salmen. Mowinckel skriver: "Sl. 132 er 'teksten' til et dramatisk formet festoptog med Jahves skrin" (Mowinckel 1951, 172). Den daværende konge har derfor imiteret David i den kultiske procession. Mowinckel beskriver det således, at David levede i kongen under riten. Kongemotivet er tydeligt og nævnes allerede i begyndelsen af Sl 132: "Herre, husk David" (Sl 132,1). Sl 132,7 beskriver formålet med optoget: "Lad os gå til hans bolig". Sl 132,8: "Herre, bryd op til dit hvilested sammen med din magtfulde ark!", læser Mowinckel som et indicium på, at man har benyttet arken i kultiske valfartssammenhænge såsom tronbestigelsesfesten. Herefter sang folkeskaren Sl 84, som ifølge Mowinckel omhandler det, at man nærmer sig templet, mens festoptoget stadig vandrer på den via sacra, som beskrives i Sl 84,6. I Sl 84,8, står der ligeledes, at de (festprocessionen) går fra kraft til kraft og vil se Jahve på Zion - ifølge Mowinckel endnu et indicium på forløbet. Jahves kultus-navn, som ofte er knyttet til situationer omkring arken, Hærskarernes Herre, benyttes fire gange i Sl 84 . Da festprocessionen ankom til templet, sang man Sl 24. Først sang de hymnen til Jahve, verdens hersker og skaber, dernæst fandt en ordveksling sted mellem portvagten og processionen om kravene for at træde ind i templet, og slutteligt lød der en opfordring om, at portene skulle oplukkes, så Jahve, Hærskarernes Herre, svævende usynlig over arken kunne drage ind igennem templets porte. Da folkeskaren var trådt ind på helligstedet/

13. Mowinckel kategoriserer Sl 8; 15; 24; 19; 33; 46; 48; 50; 66A; 75; 76; 81; $82 ; 84 ; 87 ; 114 ; 118 ; 132 ; 149$; Ex 15:1-18 som salmer med tronbestigelseskarakter (Mowinckel 1961 (1921), 4). 
tempelområdet, sang de Sl 118, der bl.a. nævner retfærdighedsporte i vers 19 (שערי צדק). Mowinckel forstår dette som en konkret port, der leder videre ind i helligdommen - de retskafne kan træde igennem den og komme tættere på alteret $(S l$ 118, 27), og derved nærmere på Jahves bolig i det allerhelligste (Mowinckel 1951, 177). Sl 118,27 understøtter Mowinckels opfattelse af processionen, da perikopen beskriver festprocessionen, som når til alterets horn og danner kæde derom.

Her i templet ved alteret, og derfor i slutningen af Sl 118, slutter Mowinckels rekonstruktion af kongeindtoget i den kultisk-mytiske kontekst. Forløbet i de fire salmer illustrerer ganske fint Mowinckels kultiske salmeforståelse. Ved hjælp af Sl 132 kan den mytologiske baggrund for festen etableres. S1 84 understreger valfartsaspektet af ritualet, idet den omhandler det at drage $o p$ til Guds helligdom. Sl 118 beskriver forløbet, efter at ritusoptoget har bevæget sig ind i selve helligdommen. Det er ikke redaktionen, samtidshistorien eller tematikkerne, der styrer læsningen, men udelukkende kultens ritualer og derfor forsøget på at forstå salmernes oprindelige funktion og formål.

\section{Sl 24: Det antifonale preludium og Herlighedens konge drager ind $i$ templet}

Mowinckels læsning kulminerer i Sl 24,7-10, hvor salmen har sit klareste antifonale og liturgiske udtryk. Forinden lovprises Jahves ejerskab over jorden og hans skaberkraft. Dernæst spørges der til folkeskarens renhed og etik, og dette ses som et kriterium for at kunne nå til templet. Derved er det centrale i processionsskaren at nå til Jahves hvilested og bære hans ark ind i det. Det at bære arken op (עלה) til templet (med udgangspunkt i S1 24,3) og identificere herlighedens konge er det rituelle, mytologisk-kultiske, hvis formål er at mindes arkens første indtog i 2 Sam $6,12 .{ }^{14}$ Der fremtræder andre centrale perspektiver og motiver, men formålet med arkprocessionen er, at Jahve er blevet konge, han er: “... in übermenschlicher Größe thront Jahwä auf - oder in - der Lade” (Mowinckel 1961 (1921), 120). Derfor skal portene slås op for ham, sådan at han kan stige op til og ind i sin bolig.

Før Herlighedens konge drager ind i templet, foregår der et liturgisk forløb frem og tilbage mellem to forskellige talende subjekter. I Mowinckels rekonstruktion af tronbestigelsesfesten tolker og identificerer han de to stemmer. Salmens liturgiske karakter begynder i v3,

$\overline{14 . ~ R o d e n ~ ע ל ה ~ o p t r æ e d e r ~ l i g e l e d e s ~ i ~ o v e r s k r i f t e n ~ ש י ר ~ ה מ ע ל ו ת ~ t i l ~ a l l e ~ s a l m e r n e ~ i ~ d e t ~}$ såkaldte Valfartspsalter (S1 120-134). 
hvor der spørges til, hvem der kan stå på Herrens bjerg, hans hellige sted. Mowinckel anser stemmen for at være én i processionen, som træder frem og spørger om, hvem der er hellige og rene til at træde op til templet. I v7 begynder selve den antifonale passage, hvor et subjekt spørger, om portene kan åbnes for herlighedens konge. Mowinckel anser stemmen for at være den samlede processions sang, som han forstår som et kor. Det efterfølgende spørgsmål om, hvem herlighedens konge er, anser Mowinckel for at være stillet af en portvagt. Den antifonale struktur må derfor opstilles på følgende måde:

Processionen: Opløft jeres hoveder, I porte, opløft jer, I oldtids døre, så han kan indtræde, herlighedens konge. ${ }^{15}$

Portvagten: Hvem er herlighedens konge, der?

Processionen: Jahve, stærk og mægtig, Jahve, mægtig i krig.

Folkeskaren: Opløft jeres hoveder, I porte, opløft jer, I oldtids døre, sådan at han kan træde ind, herlighedens konge.

Portvagten: Hvem er han, herlighedens konge der?

Processionen: Hærskarernes Herre, han er herlighedens konge.

Denne antifonale struktur, hvor der veksles imellem forskellige talende subjekter, er blevet sat i musik adskillige gange i musik- og kirkehistorien. I det følgende vil jeg se på, hvordan dette kommer til udtryk i G. F. Händels (1685-1759) Messiah: A Sacred Oratorio.

\section{IV: Händels Messias - baggrunden for værket og librettoens tilblivelse}

I kor 30 Lift up Ye Heads i Messias fortolker Händel Sl 24. Korværket betoner de samme motiver og bevægelser, som Mowinckel gør i sin kultisk-liturgiske rekonstruktion af Sl 24. Før jeg kan give en meningsfuld analyse af Händels læsning af salmeteksten, præsenterer jeg indledningsvis Händel og oratoriegenren, den kirkehistoriske og

15. I opstillingen bruger jeg min egen oversættelse frem for 1992-oversættelsen. Dette skyldes primært, at jeg ønsker at understrege brugen af de demonstrative pronominer og at oversætte הכבוד med herlighed frem for are. 
politiske kontekst i Händels samtid, da den historiske kontekst er central for den receptionshistoriske tilgang.

\section{Tyskeren Händel og det engelske oratorium}

Händel (1685-1759) blev født i Halle, men flyttede til England i dronning Annes regeringstid i 1712 og boede der indtil sin død i 1759 . I 1710 have Händel været kapelmester hos kurfyrsten af Hannover, som senere skulle blive George I, konge af England. Således har Händel kendt George, før han overtog tronen i 1714. I 1706-10 var Händel bosat i Rom. I den periode komponerede Händel latinsk kirkemusik - heriblandt kantater og to oratorier. Oratoriet var efter alt at dømme ikke en særligt udviklet musikalsk genre, da Händel kom til England i 1712. De tidligste eksempler på engelske oratorier er John Hiltons (1599-1657) to "sacred dialogues", The Dialogue of King Solomon and the Two Harlots og The Dialogue of Job, God, Satan, Job's Wife and the Messenger fra $1616 .{ }^{16}$ Sådanne "dialoger" viser, at der har været dramatiseret musik, baseret på bibelske fortællinger i perioden. Dog var der formentlig ikke tale om en egentlig engelsk oratoriegenre. Det såkaldte "engelske oratorium" som en særlig oratorium-stil er Händels fortjeneste. Genren blev baseret på en form for syntese af Händels musikalske uddannelse i mange forskellige landes kirkelige og musikalske traditioner. Händels "engelske oratorium" er således baseret på den italienske opera seria ${ }^{17}$, den latinske kirkemusiks koriske harmonisering af Salmernes Bog, det tyske oratorium, det franske drama og den engelske kormusik (Smither 1977, 178).

Overordnet set kan man sige, at oratoriegenren kommer fra Italien. Oratorium betyder bedesal og er en stedsangivelse af, hvor man udførte denne form for musikalske andagter. Derved er ordet senere kommet til at definere en musikalsk genre, som overordnet set består af musikalske dramaer, som blev opført i broderskabs-bedesale. Teksterne kom som regel fra bibelsk litteratur, mens den musikalske stil på mange måder ligner operaen. Oratorium er en overordnet genrebetegnelse, da den dækker over mange forskellige typer af musikalske dramaer. Detengelske oratorium adskiller siggenremæssigt fra andre oratorier ved, at koret får en mere fremtrædende rolle i den

16. Howard E. Smither, A History of the Oratorio vol. 2, The Oratorio in the Baroque Era - protestant Germany and England (Chapel Hill: The University of North Carolina Press 1977), 175.

17. Opera seria var en veldefineret genre på Händels tid, hvor al handling udspiller sig i enkelte recitativer, og hvor der i arier udelukkende udtrykkes enkelte følelsesudbrud. 
dramatiske repræsentation af bibelske tekster. ${ }^{18}$ I den forbindelse er det værd at notere sig, at enkelte i Händels samtid mente, at Messias ikke var et rigtigt oratorium genremæssigt, da stykket ikke var dramatisk nok i sin struktur. ${ }^{19}$ Der er dog uden tvivl en sammenhæng mellem Messias og den italienske og tysk-protestantiske oratoriegenre. På den måde kan man sige, at Händel bragte kulturelt gods med sig fra kontinentet til England og udviklede en særlig engelsk udgave af oratoriet. Dette skete i en periode, hvor der var store ændringer i det engelske monarki, da en tysker skulle arve den engelske trone.

\section{Varkets historiske kontekst}

Disse ændringer skyldtes først og fremmest, at Tolerancetraktaten af 1689 vandt indpas i Vilhelm IIIs regeringstid (1689-1702). ${ }^{20}$ Traktaten erklærede den anglikanske kirke som statskirken i England og tillod tolerance over for de protestantiske "afvigere", som blev tilladt forsamlings- og kultusfrihed. ${ }^{21}$ Katolikkerne derimod blev underlagt hård tvangslovgivning. Det største problem for Vilhelm III var dog ikke de engelske katolikker, men de gejstlige non-jurors, som ikke ville aflægge ed. ${ }^{22}$ Disse non-jurors organiserede sig efterfølgende delvist i, hvad de kaldte den "sande katolske kirke", som ikke knyttedes direkte til den romersk-katolske kirke og derfor forblev en "katolsk" engelsk kirke.

Wilhelm IIIs efterfølger var dronning Anne. Hendes regeringstid (1702-1714) var kendetegnet ved en rig opblomstringsperiode inden for kultur- og kirkeliv. Den herskende kirkeretning inden for den anglikanske kirke var i denne tid latitudinarismen, som repræsenterede en bred, "frisindet" kirke. I 1714 overtog den hannoveranske konge George I tronen som 54-årig. George I arvede tronen pga. den såkaldte "Act of Settlement" fra 1701, som forbød katolikker at arve tronen i England. Intet mindre end 50 katolikker stod foran George

18. Nils Holger Petersen, Händel - Messias: originalteksten med dansk oversattelse: baggrund og fortolkning (København: Det Danske Bibelselskab 2004 (1992)), 59-65. 19. Fx John Brown som skrev: "Thought that grand Musical Entertainment (Messiah) is called an Oratorio, yet it is not dramatic; but properly a collection of Hymns or Anthems drawn from the sacred Scirptures; In strict Propreiety, therefore, it falls under another Class of Composition" (Smither 1977, 255).

20. Carsten Bach-Nielsen, Kirkens historie (København: Hans Reitzels Forlag 2012), 333.

21. Martin Schwarz Lausten, Kirkehistorien (København: Anis 1997), 208.

22. Charles Jennens, Händels librettist, var en non-juror og kunne derfor ikke træde ind i politiske eller kirkelige embeder, da magten i London på det tidspunkt lå helt i hannoveranske hænder (Donald Burrows, Handel Messiah (Cambridge: Cambridge University Press 1991),9). 
I i arvefølgen. Händel skrev først Messias i George IIs regeringstid (1727-1760). George II var opvokset i Hannover, og efter faderens ønske komponerede Händel musikken til sønnens kroning. Her benyttede Händel 1 Kong 1,38-40 i et af sine mest kendte musikstykker Zadok the Priest til at legitimere monarkiet med et gammeltestamentligt, teologisk fundament. Da Händel skrev Messias, fik han kyndig hjælp til at udvælge de rette passager til librettoen - da man med denne ønskede at bevise hele Bibelens sandhed ud fra skriften selv.

\section{Jennens' og Händels fortolkningsstrategier}

Charles Jennens (1700-1773) sammensatte hele librettoen til Händel. Jennens ønskede, at teksten skulle være en bibelmosaik af passager fra hele Bibelen. Den primære kilde til librettoen var King Jamesbibelen. Jennens har dog i enkelte satser, ${ }^{23}$ navnlig i passionsdelen af værket, ændret på de personlige pronominer f.eks. fra "I" til "he". Jennens foretog ændringerne som led i sin kristologiske tolkning af de gammeltestamentlige passager (Petersen 2004, 53). Hans ændringer er foretaget af passager, som traditionelt er fortolket messiansk for at understrege sammenhængen mellem GTs skrifter som profetiske udsagn om Jesu lidelse, død og opstandelse. Passagerne er bl.a. fra de to sidste tjenersange ${ }^{24}$ i Es 50,4-11 og 52,13-53,12 og Sl 22.

Det primære teologiske formål med Jennens' tekstudvalg var at føre bevis for bibelens sandhed. Librettoen skulle bevise GTs foregribelse af NTs begivenheder (Petersen 2004, 51). Tekstudvalget beroede således først og fremmest på en typologisk udlægning af GT, som er og har været et centralt fortolkningsprincip igennem den kristne, liturgiske fortolkning af bl.a. Salmernes bog. Typologi betegner en skriftudlægningsmetode, som allerede benyttes i NTs udlægning af GT. ${ }^{25} \mathrm{I}$ sin mest basale form trækker metoden på en typos fra GT, eksempelvis en person eller en begivenhed, som forstås som en foregribelse af Jesu Kristi evangelium. ${ }^{26}$ Fortolkningsprincippet opfattedes allerede i oldkirken som en af de mest centrale læsninger i forbindelse med forståelsen af relationen mellem GT og NT. ${ }^{27}$

23. Satserne: 17, 20, 24, 26-29.

24. Ifølge B. Duhms opdeling af de fire tjenersange i Deuteroesajas (Das Buch Jesaia übersetzt und erklärt (Göttingen: Vandenhoeck \& Ruprecht 1892).

25. Eksempelvis i Rom 5,14 om Adam: "Han er et billede på ham, der skulle komme" (DO 1992).

26. Stuart George Hall, TRE 34 (Berlin - New York: Walter de Gruyter 2002), 208.

27. Fx ved Justin Martyr (100-165) som mente, at en af de tre overordnede skrifttyper i GT var profetiske og typologiske udsagn om Kristi evangelium (Siegfried Reader, TRE 27 [Berlin - New York: de Gruyter 2002], 625). 
Salmernes Bog er blevet fortolket typologisk igennem hele kirkehistorien, og salmerne har haft en central placering i kirkens liturgi, musik og i bønssammenhæng. Skriftet er overordnet set blevet brugt på to måder i liturgiske sammenhænge: Enten som en særlig visdomslitteratur, hvor man anser hele psalteret som én særlig visdomsskole, lectio continua, eller med fokus på enkelte salmer og disses profetiske karakter, som har en særlig placering i frelseshistorien..$^{28}$

Den typologiske fortolkning af gammeltestamentlige skriftsteder (særligt i Salmernes Bog) var den primære fortolkningsnøgle, som Jennens og Händel var afhængige af i udformningen af Messias. Således er deres metode, og derved den typologiske brug af S1 24,710 i Lift up Ye Heads, ikke en nyopfindelse, men en allerede kendt fortolkningsstrategi. Sådan kædes skrifterne sammen, og fungerer som en messiansk bevisførelse inden for Bibelens skrifter. Den typologiske læsning har naturligvis udviklet sig meget i perioden fra den oprindelige nytestamentlige brug til Händels og Jennens' brug af den. Fortolkningsmetoden blev etableret i den tidlige kirke og får en stigende indflydelse igennem middelalderen. I højmiddelalderen (ca. 1000-1300) er den typologiske læsning så udbredt, at man kan finde eksempler på den påstand, at hele GT repræsenterer en række typer, som forudgriber Kristi komme. På den måde benytter man hele GT som en udpræget kristen fortælling, der peger frem imod Kristus. Den typologiske læsning bliver modificeret i tiden efter reformationen, hvor den overordnet set bliver mindre anvendt. ${ }^{29}$ Händel og Jennens' typologiske læsning af de gammeltestamentlige passager benyttes til at bevise kontinuiteten mellem GT og NT. Derfor er strategien ikke præcis den samme som den højmiddelalderlige typologiske skriftforståelse, men der skal ikke sås tvivl om, at læsningen har en profetisk intention, som "afsløres" i selve titlen på værket Messias. I Messias er de gammeltestamentlige passager udvalgt i et kristent, teologisk øjemed.

Librettoen til Messias indeholder samlet set 73 bibelvers. 43 af dem er fra GT, og 30 er fra NT. De to mest citerede skrifter er Esajas' bog (22 vers) og Salmernes Bog (14 vers). I forbindelse med struktureringen af librettoen er det ikke uvæsentligt, at Jennens benytter passager fra GT, som citeres i NT (fx Arie 3, hvor Es 40,1-3 benyttes, som citeres i Luk 3,5), passager fra NT, som er citater af GT (fx i Kor 18 som citerer Matt 11,30, der er et citat fra Jer 6,16) og passager fra GT, som

28. Angelus A. Häußling, RPP 10 (Leiden - Boston: Brill 2011), 499-500.

29. For en uddybning af typologiens idehistoriske udvikling se evt. E. Auerbachs essay Figura (1938) i Scenes from the Drama of European Literature (Minneapolis: University of Minnesota Press 1984), 11-76. 
i høj grad ligner passager, som senere forekommer i NT (fx Arie 6, som bygger på Mal 3,2, men som ligeledes ligner Åb 6,16-17). ${ }^{30}$ På den måde understreger Jennens med sit tekstvalg og sin strukturering af passagerne, at de "typologiske beviser" eksisterer i selve Bibelens relation mellem GT og NT. Opbygningen i værket er derfor centralt for forstålsen af selve læsningen af SI 24.

\section{Messias' opbygning og kor 30 Lift up Your Heads' kontekst i librettoen}

Messias er opdelt i tre hoveddele. Den første del strækker sig fra værkets åbningssymfoni til kor 18 His yoke is easy, His burthen is light. Den anden del begynder med kor 19 Behold the Lamb of God til kor 39, det folkekære Halleluja. Den tredje del påbegyndes med Arie 40 for sopran I know that my Redeemer Liveth og ender med kor 47 Worhty is the Lamb that was slain og et stort amen. Librettoen er opbygget analogt med frelseshistorien: Jesu fødsel - Jesu død og opstandelse - de sidste tider.

Brugen af Sl 24,7-10 i Lift up Ye Heads udgør både et midtpunkt og vendepunkt i anden del af Messias. Anden del (nr. 19-37) påbegyndes også med Johannes Døberens skikkelse og rolle i frelseshistorien. De indledende ord i kor 19 er fra hans vidnesbyrd om Jesus i Joh 1,29: "Behold the Lamb of God, that taketh away the sin of the world". Umiddelbart herefter kommer den længste "bevægelse" i hele oratoriet, en alt-arie, hvis første del spilles i largo. Arien citerer Es 53,3: "He was despised and rejected of men, a man of sorrows and acquainted with greif". I midten af arien skifter Jennens skriftstedet fra den fjerde tjenersang (Es 52,13-53,12) til den tredje (Es 50,4-11). Es 50,6 fungerer som et uddybende intermezzo i sammenhængen, den mand der var "despised" og "rejected" "[He] gave His back to the smiters [...] He hid not his face from shame and spitting". Händels musik skifter også karakter i arien, den bliver staccato-præget og hurtigere. I kor 21-23 vender librettoen tilbage til Es 53,4-6. Passagen beskriver formålet med fornedrelsen af manden i Es 50,6: "And with His stripes we are healed". Jennens beskriver soningsdøden igennem de to tjenersange - Messias' fornedrelse og korsdød er kriteriet for vor frelse. I recitativ 24 og kor 25 citeres S1 22,8-9. I denne passage kommer tematikken atter op, hvor spotten og hånen er i fokus, som $\mathrm{i}$ arie $20 \mathrm{~b}$. I de to satser er der dog den udvikling, at spotten denne gang går på, at den lidende mand stoler på, at Gud vil redde ham,

30. Michael Marissen, Tainted Glory in Handel's Messiah, (New Haven: Yale University Press 2014), 86-87. 
selvom det umiddelbart ikke ser ud til at blive tilfældet for dem som spotter. Det beskrives også samtidigt, at han har lagt sin sag i Herrens hænder. Recitativ 26 og arioso 27 citerer henholdsvis S1 69 og Klages 1,12. Jennens har ændret en del i grundteksten i disse passager. Sl 69, som er en individuel bønssalme i 1. prs., kommer til at omhandle Messias i 3. prs.: "He looked for some to have pity for him...”. I Sl 69,21 i MT står der לבי "ל altså et substantiv med 1. prs. pronominalsuffiks: "mit hjerte". Det samme gælder arioso 27, hvor Klages 1,12 citeres. I passagen synger Judas datter om sin smerte, men her bliver det "His sorrow". Recitativ 28, som bygger på Es 53,8, må opfattes som Messias død på korset: "He was cut off out of the land of the living".

Arie 29 er det store vendepunkt, hvor passionstematikken fra sats 19-28 afsluttes. ${ }^{31}$ Musikken skifter fra mol til dur, og tenorarien citerer Sl 16,10: "But Thou didst not leave His soul in hell; nor didst Thou suffer The Holy one to see corruption". Sl 16,10 fortolkes messiansk og kommer til at omhandle opstandelsen, ligesom Peter tolker den i ApG 13,35, da han prædikede i Antiokia. Portene i kor 30 (SI 24,710) kan derfor have en dobbelt betydning, de kan være himmelens tempelport eller helvedes porte. Derved understreger passagen Jesu kamp i dødsriget, når han sprænger dødsrigets port op og besejrer døden. ${ }^{32}$ Sl 24,7-10 fungerer herved som overgangen fra død til liv i librettoen - Jesus kæmpede i verden mod døden. Kampmotivet er derved trukket i forgrunden i kor 30. Kristi sejr over døden i 24,7-10 er en skabelseskamp; Kristi kamp for liv i verden lader således til at være analog med Jahves kaoskamp i den hymniske del af Sl 24,1-2.

Daniel I. Block skriver følgende om Jennens og Händels læsning af salmen:

Jennens appeals to Psalm 24:7-9 to paint a celebrative picture of a triumphant King marching up to the Temple on Mount Zion. As a divine warrior the Messiah has triumphed over death. The psalmist calls on the gates of Zion and the gates of the Temple to open wide for the King. ${ }^{33}$

31. Passionstemaet er navnlig skrevet over fragmenter fra tre messianskfortolkede klassikere: Sl 22, Es 50,4-11 og Es 53.

32. En opfattelse af Jesus nedstigen til dødsriget, som bl.a. ses hos Origenes og Kyril af Jerusalem, og i nyere tid hos N. F. S. Grundtvig i I kvald blev der banket $p a$ Helvedes port (DDS 213).

33. Daniel I. Block: "Händel's Messiah: biblical and theological perspectives", Didaskalia (2001), 1-23. 
Man kan dog indvende imod Block, at der først er en stedsangivelse med "up on high" i arie 32, og at Zion først nævnes i nr. 34. Kristus er altså herlighedens konge, מלך הכבוד som skal drage igennem templet/himmelens port. Passagen viser således tilbage til librettoens begyndelse og forjættelsen om Johannes Døberens råb i ørkenen (Es 40,1-5), at Herrens herlighed, כבוד, skal åbenbares.

I det følgende recitativ og kor 31 tolkes herlighedens konge som Guds søn, sådan som han beskrives i Hebr 1,5-6. Derved bekræftes det, at Kristus er Herlighedens konge - en typologisk tolkning som klinger fint med betydningen bag Kristus-Messias titlen, som Jahves salvede. Perikopen bygger på Sl 2,7 og Sl 97,7. Det er interessant at begge salmer betegnes som tronbestigelsessalmer i Mowinckels Psalmenstudien II. I arie 32 fortolkes Sl 68,19 som et vidnesbyrd om, at opstandelsen allerede er sket, her skal Gud Herren bo - altså Kristus, Herlighedens konge. Fra kor 33-35 beskrives forkyndelsen af evangeliet, dernæst beskrives modtagelsen af evangeliet fra arie 36-37. Anden del afsluttes med en beskrivelse af Guds sejr i tenorarie 38 og det store halleluja i kor 39. Læsningen af S1 24 i kor 30 betoner således Kristi sejr i dødsriget. Det interessante i forbindelse med denne artikel er dog ikke læsningens sigte, men i højere grad, hvordan læsningen på flere måder strukturelt set ligner den, som man finder i Mowinckels eksegetiske læsning af teksten.

\section{Gennemgang af Händels lasning af Sl 24,7-10 i kor 30 Lift up your heads}

Händels fortolkning af Sl 24,7-10 er indbefattet i kor 30, som bevæger sig over 77 takter. Satsen følger fuldstændig teksten i Sl $24 \mathrm{~s}$ forløb. Salmetekstens antifonale struktur er tydelig at spore i kompositionen. De første 30 takter af koret synges med to opdelte svar-spørgsmåls-grupperinger. Satsen begynder derfor med, at sopran I, sopran II og alter beder om, at portene skal slås op. Dette besvares af tenorer og basser: "Who is this King of Glory?" Sopraner, alter og tenorer besvarer spørgsmålet: "The Lord strong and mighty, the Lord mighty in battle". Den samme struktur gentages, ligesom salmens opbygning, men i gentagelsen er grupperingerne dog spejlvendte med undtagelse af altstemmen, som forbliver en del af den spørgende stemmegruppe. Dette kan opfattes som et udtryk for Kristi kamp mod dødsriget. Denne fortolkning beror på det grundlag, at de lyse stemmer i begyndelsen repræsenterer opstandelsens lys, og de mørke mandsstemmer kan forstås som helvedes. Spejlvendingen af stemmerne understreger ligeledes overgangsstrukturen, idet de lyse stemmer først spørger, om de kan passere det mørke, altså helvedet, 
og dernæst beder de mørke/dybe stemmer, som repræsenterer det jordiske, om at stige op til det lyse, altså himmelens port.

Vekselsangen mellem de to rolle- og størrelsesskiftende grupper fortsætter indtil takt 32, hvor alle stemmerne synger samtidigt. Herefter synger koret over de to forskellige epiteter til herlighedens konge, som i Händels læsning er Kristus og hærskarernes Herre, som også er Kristus. Koret ender med at fremhæve, at Kristus er herlighedens konge.

Händels iscenesættelse af S1 24,7-10 i oratoriet fremhæver det antifonale/liturgiske element i salmeteksten. Det er tydeligt, at der synges mellem to talende grupperinger, hvor den spørgende konsekvent indeholder færre stemmer end den besvarende. Det er muligt, at Händel har forsøgt at fremhæve det liturgiske præg i salmen, da han kendte til opstandelsesceremonielle traditioner fra middelalderens klostre og katedraler, hvor S1 24,7-10 benyttedes til gudstjenesten påskedag (Petersen 2004, 57). Uagtet den betragtning er Händels læsning af passagen messiansk og har strukturelt set mange lighedspunkter med Mowinckels kultiske rekonstruktion af teksten.

\section{V: Strukturelle og teologiske ligheder og forskelle mellem Mowinckels og Händels receptionshistoriske læsninger af Sl 24,7-10}

Som allerede pointeret er der mange lighedspunkter mellem Händels musikalske fortolkning og Mowinckels eksegese af Sl 24, men der er naturligvis også afgørende forskelle. Primært forsøger de to læsninger at fremhæve to forskellige ting, men så at sige på parallel vis. Mowinckels læsning af Sl 24 fremhæver den kultorienterede folkeskare og Jahves indgang i templet. Händels læsning omhandler Kristi kamp imod døden, livets sejr og opstandelsen.

Det mest centrale lighedspunkt i læsningerne er den strukturelle lighed. Mowinckel forestillede sig, at én enkelt portvagt spurgte: "Hvem er herlighedens konge?" og at en større folkeskare besvarede spørgsmålet. Både forståelsen af strukturen og størrelsesforholdene mellem de talende subjekter i liturgien går tydeligt igen i Händels fortolkning af Sl 24.

Hvad angår læsningernes bagvedliggende metodik, så minder disse umiddelbart også om hinanden. Hverken Mowinckel eller Händel tager højde for kanons sammensætning og slet ikke for den almindelige femdeling i Salmernes Bog. De "fisker" i skrifterne for at 
nå frem til deres resultater. Mowinckel nøjes med psalteret og få dele af de gammeltestamentlige skrifter, Händel benytter sig derimod af hele kanon og foretager små fortolkende omskrivninger af teksten, for at accentuere sine motiver og sin kristne tolkning.

Mowinckels rekonstruktion af tronbestigelsesfesten, hvor Jahve blev båret til templet, anser Mowinckel Sl 24,7-10 som den umiddelbare situation, inden Israels folk valfarter ind i selve templet. Efter at folkeskaren har sunget Jahves kultus-navn, יהוה צבאות, træder de ind. Denne "scene" er analog med Händels struktur i koret. Da musikken går fra første til anden del i korsatsen, går den fra et homofont og antifonalt lydbillede til et overvejende polyfont. ${ }^{34}$ Ændringen giver musikken en klar fremtoning af bevægelse. Valfarts- og processionstematikken og dennes sakrale karakter i kulten i Mowinckels læsning af salmens rituelle baggrund passer altså ind i Händels fortolkning. Mowinckels forståelse af processionens bevægelse og dens afsyngning af valfartssange, שיר המעלות, fra S1 132,8-10, ad en via sacra, som beskrives i Sl 84,6 før deres indtog i templet, efter at porten er blevet slået op i Sl 24,7-10, svarer til bevægelsen i Händels korsats.

I Mowinckels læsning ligger det overordnede fokus på bevægelsen עלה (S1 24,3), som beskriver den kultiske rite at gå op til helligdommen. Det primære fokus er altså det lokative i processionen, selve Jahves trones bevægelse udenfor Jerusalem op til templet. Den opadgående tankegang forekommer også i Händels læsning, men her er det primære fokus Jesu himmelfart og overgangen fra dødsriget til livet. I Mowinckels læsning må det betyde, at Jahve drager op til templet, svævende over sit hellige skrin, pagtens ark, i procession med Israels syngende folkeskare. I Händels fortolkning, og derfor i en kristen typologisk læsning, er billedet analogt med opstandelsen. Bevægelsen er lokativ fra Kristi sjæl i "hell” (arie 29) til "up on high" (arie 32), men det primære fokus ligger på sejren over døden.

I Händels tolkning af Sl 24 er pointen, at når Kristus træder igennem tempelporten, da sejrer livet, Kristus overmander døden. Et af de mest afgørende ledemotiver i Mowinckels forestilling om Jahves tronbestigelsesfest er, at festen er en høstfestsfejring og en fejring af, at kaosmagterne blev (og bliver) nedkæmpet - Jahves såkaldte creatio continua. Dette er et centralt ledemotiv, som Mowinckel ligeledes sporede i den assyriske nytårsfejring.

34. Med homofont menes der, at der synges flerstemmigt, men at der er en struktur og en hovedstemme, som dominerer lydbilledet og derved underordner de andre stemmer sig denne. Begrebet kan også betegne stringent enstemmig musik som $\mathrm{fx}$ gregoriansk sang. 


\section{Fortolkningskontinuitet eller oprindelig struktur - afsluttende diskussion}

Mowinckels og Händels læsninger af S1 24,7-10 sigter tydeligvis mod vidt forskellige mål. Mowinckel forsøger at rekonstruere kulten ud fra psalteret, Händel forsøger "at bevise" GTs foregribelse af NTs begivenheder igennem en musikalsk, typologisk fortolkning. På trods af disse forskelle betoner deres læsninger de samme tematikker, hvad angår stemmeidentifikation, struktur og antifonal sang mellem to forskellige grupperinger af to forskellige "størrelser". Händels kristne, typologiske tolkning af Sl 24,7-10 kan derfor bestyrke Mowinckels receptionshistoriske læsning, som forsøger at rekonstruere kultens ritualer ud fra det formkritiske ønske om at forstå en teksts Sitz-imLeben. De fælles læsninger beviser dog på ingen måde, at der rent faktisk har eksisteret en tronbestigelsesfest, og at man kan bevise eksistensen af et sådant ritual med Salmernes Bog som en form for libretto og hovedkilde. Læsningen får dog Mowinckels eksegetiske tolkning af psalteret til "at stå mindre alene".

Det er interessant i forbindelse med læsningen af S1 24 at undersøge to forskellige "kultiske religioners" fortolkning af samme salmetekst og herigennem iagttage de fælles strukturer, som unægtelig tegner sig i receptionshistorien. Mowinckels såvel som Händels læsning understreger Guds kamp imod døden - henholdsvis Kristi sejr over dødens magt og Jahves kamp imod kaosmagterne. Der er i begge fortolkninger fokuseret på, at Guds kamp altid er en opretholdelseskamp for livet. Læsningerne peger også begge på det "at gå op" som en form for dobbeltbevægelse. Kristus stiger op til himlens port i sin himmelflugt. Jahve går op til sit hvile- og helligsted i procession til templet. Udover de interessante tematiske sammenfald i de to læsninger, så skal det understreges, at det også er centralt i sammenstillingen af de to læsninger, at det er muligt at behandle Mowinckels eksegese i Psalmenstudien II som et form for nedslag i Sl 24s kultur- og receptionshistorie på samme måde vis som Händels Messias.

I den forbindelse kan det diskuteres, hvorvidt den kristne, kirkemusikalske fortolkning af Sl 24 har fungeret som en slags hermeneutisk horisont for Mowinckels eksegese. Det kan i sagens natur ikke bevises, men sammenfaldet i de to fortolkninger ud fra overstående gennemgang er påfaldende. Her er det ikke uvæsentligt at påpege, at Mowinckels opfattelse af kulten i Psalmenstudien II baseres på en form for komparativ metode. For at understrege tidligere fortolkningers misforståelse af det kultiske element, benytter han et eksempel fra den romersk-katolske kirke (Mowinckel 1961 (1921), 33). Der nævnes i denne forbindelse intet om psalteret selv eller for 
den sags skyld om en typologisk opfattelse af salmerne. Dog skriver Mowinckel:

Es ist denn auch eine bekannte Tatsache, Daß der dem Kulte immanente Trieb zum Drama auch im katholischen Mittelalter sich auf vielen Punkten geltend gemacht hat. Es genügt hier, aus die Passionsspiele und die Weihnachtsspiele, die beide noch fortleben, wenn auch z. T. von dem Gottesdienste losgetrennt, hinzuweisen (Mowinckel 1961 (1921), 34).

De passionsspil, som Mowinckel henviser til i citatet ovenfor ${ }^{35}$, har deres udspring i den tidlige middelalders dramatiske liturgi, hvor Sl 24,7-10 blev fortolket typologisk som en beskrivelse af Jesu Kristi opstandelse fra de døde. Mowinckel trækker ingen paralleller direkte hertil, men Mowinckel orienterede sig ift. de middelalderlige passionsspil, som strukturelt set har visse fællestræk med fortolkningen i Psalmenstudien IIs beskrivelse af Jahves tronbestigelsesfest og i alle henseender til processionskulturen, der var central i forbindelse med passionsspillene. Der kan altså være tale om en anakronisme i Mowinckels eksegese af Sl 24, hvor kirkens repræsentation i liturgi, procession og drama har fungeret som en mere eller mindre ubevidst hermeneutisk baggrund. Argumentet får ekstra tyngde og slagkraft, hvis man inddrager Hans J. Lundager Jensens pointe om, at Jahve-religionen bestemt var en religion, hvor der var fester, men ikke en religion, hvor der var rituelle processioner. ${ }^{36}$ Dette hænger sammen med, at man ikke havde templer i Jahve-religionen på samme måde som i arkaiske religioner. For i arkaiske religioner var templerne bygget, så man kunne fremvise helligdomme, som skulle transporteres og fremvises i processioner - dette harmonerer ikke med billedforbuddet i den "nye" Jahve-religion. H. J. Lundager Jensen

35. Mowinckel henviser i en fodnote, når han taler om Passionsspiele i Psalmenstudien II: “Vgl. Süß, Passionsspiele, RGG IV”, og dette henviser til Dr. W. Süß' artikel i $R G G 4$ fra 1913, som blandt andet Gunkel var medudgiver på. Artiklen Passionsspiele er lang og grundig gennemgang af forskellige indflydelser på passionsspillene i kirken. Her gennemgår Süß for eksempel de udgaver af Mark 16,6-7 som man har brugt til Matutin-bønnen på påskesøndag i middelalderen (Hermann Gunkel og Otto Scheel, $R G G 4$ (Tübingen: Mohr Siebeck 1913), 1246). Dette er også de såkaldte Quem quaeitis-spil. Selvom denne tekst omhandler kvinderne, som besøger Jesu grav, så er strukturen i disse spil et drama, hvor der spørges, hvem kvinderne søger. Herefter svares en anden stemme Jesus fra Nazareth og til sidst forklarer en stemme, at Jesus er opstanden og ikke længere er i graven. Der er visse strukturer i disse rituelle dramaer, som ligeledes ligner Mowinckels fortolkning af Sl 24.

36. Hans. J. Lundager Jensen: "Om dejlige dage: Hiero- og teofore processioner i arkaisk religion og i Det Gamle Testamente”, RVT 66 (2017), 78-104. 
påpeger, at man måske kan argumentere for, at man kan betragte Corpus Christi-processioner, som stammer fra middelalderen, som en form for tilbagevenden til en arkaisk teofor procession, hvor man bærer en guddom frem. Han mener dog ikke, at man kan forsvare, at der findes sådanne processioner i GT. ${ }^{37}$ Dette antyder for det første en metodisk fejlkobling i Mowinckels eksegese, som muligvis bunder i en forsimpling, der skyldes den komparative metode, som er helt central for Mowinckels teori om tronbestigelsesfesten og processionsritualet i Sl 24. For det andet tyder det på, at Mowinckel har været præget af processionskultur og passionsspil, som ikke har en egentlig relation til GT. Mowinckels forsøg på at betone det centrale i at betragte "det kultiske" grundelement i religionen i Psalmenstudien II ender med at fælde hans egen teori, da den forsimpler religionerne og ender med at bedrive anakronistiske argumenter for tronbestigelsesfesten.

Det er i denne forbindelse også interessant at overveje fortolkningssammenfaldet ud fra formkritikkens præmisser. Man kan overveje om selve strukturen i Sl 24,7-10 fordrer en antifonal fortolkning af teksten. I så fald kan det muligvis antyde en oprindelig kultisk situation, hvor teksten eventuelt har været skrevet med henblik på at blive udsagt af forskellige subjekter/grupperinger. Det er umuligt at komme det nærmere end overvejelser eller indicier, hvis man ikke vil ende med at gå for vidt ligesom Mowinckel. Men struktursammenfaldet i salmens receptions- og fortolkningshistorie antyder enten kontinuitet $i$ fortolkningstraditionen - i kunsten og eksegesen - eller muligvis en fælles struktur i selve salmeteksten, som indbyder og kræver en form for antifonal læsning af SI 24.

37. Hans. J. Lundager Jensen: "Processioner: Indledning”, RVT 66 (2017), 3-13. 